\title{
WHY OUGHT WE TO OBEY THE LAW? PLATO'S STARTLING ANSWER
}

\author{
A Domanski (University of the Witwatersrand)
}

Picture this scenario. Criminal charges have been brought against you. You are tried, convicted, and sentenced to death. (Mercifully, this could not happen in present-day South Africa.) While you have been given a procedurally fair trial, the charges brought against you and your conviction are substantively unjust. You are now in prison. Two days hence you are to die. What is your state of mind? Calm? Agitated? Depressed? Now suppose a friend arrives to visit you. He tells you that plans have been made for your escape, that your warder can easily be bribed, and that a car is waiting outside to whisk you away to a safe and secret destination. How do you react? Rejoice and run? Stay put and face the prospect of death? Most people in such a situation, we may agree, would escape without hesitation.

In about 400 B.C., the Athenian philosopher Socrates found himself facing just such a situation. His response is graphically and poignantly recorded in Plato's dialogue, Crito. The calm, objective manner in which Socrates examines the situation, weighs up the arguments for and against escape, and arrives at his decision is a magnificent and timeless example of the use of reason. There is much that our country, assailed by widespread disrespect for the law, can learn from his example.

The question under examination in the Crito is germane to all societies and all ages; it has to do with the relationship between the individual and the state. More particularly, the issue is the citizen's duty to obey the law. Does such a duty exist? If so, how far does it extend? Is it conditional or unconditional, absolute or qualified? Does it perhaps depend on the fulfilment of reciprocal duties by the state? These are important and controversial questions in contemporary jurisprudence. They are especially pertinent to this country, which for almost half a century has toiled under the yoke of apartheid laws. In the view of many, those laws were not worthy of obedience.' The same, however, cannot be said of the laws of Athens, by the operation of which Socrates found himself in prison, condemned to die.

The Crito is not the only dialogue in which Plato deals with the relationship between the individual and the state: the Republic, the Laws, the Statesman, and other dialogues also explore this evergreen theme. This article, however, deals exclusively with perspectives contained in the Crito. ${ }^{2}$

1 Today still, five years after the demise of apartheid, the citizen's duty to obey the law (assuming that such exists) is widely ignored in South Africa.

2 The Crito, the foundational Western text on the citizen's duty to obey the law, has attracted the attention of many modern commentators. Sadly, most of them do no more than emphasize the estrangement between the tortuous complexities of modern analytical philosophy and the simple, universal values of Socrates and Plato. A vivid illustration of the vastness of this chasm is to be found in a view expressed in all seriousness by a distinguished modern scholar in the field of Platonic studies: according to Gregory L Vlastos (1974:517), Socrates in the Crito is intuitively sensing and groping towards Rawls' and Hart's principle of fairness, though the Crito falls short of formulating or explicating the principle, "presumably because Plato lacked either the clarity of 
Why was Socrates in prison? What had he done? Socrates believed he had a duty, imposed on him by God, to question his fellow-Athenians (Apology 22a, 30a). His aim was to expose pretence, to remind people of truth, to remind them that there are values higher than material success. Socrates taught that the unexamined life is not worth living. In the process, he trod on important toes and made many enemies. Three of them accused him of heresy and of corrupting the minds of the youth of Athens. He was duly tried, convicted by a narrow majority of the 501 Athenian citizens present in the assembly, sentenced to death, ${ }^{3}$ and imprisoned, to await the carrying out of the sentence.

As the dialogue opens, Socrates' friend Crito visits him in prison in the early morning, in order to persuade him, not for the first time, to escape (43a). Expecting to find his friend in a state of agitation, Crito is astonished to find him peacefully asleep. When Socrates awakens, his manner is easy and tranquil. He shows complete indifference to the prospect of impending death. Crito entreats him to agree to escape (44b), adding that if he does not, he and other friends of Socrates will incur disgrace, for most people will not believe that they wanted Socrates to escape and that he refused to do so. Socrates is unmoved: what counts in his view is the opinion of good men, not of the many. The multitude is governed by chance, and is incapable of conscious action, whether for good or evil (44c-d). ${ }^{4}$ It is this sharp contrast in attitude and values between Socrates and Crito that gives the dialogue its tension: Crito's thinking is conventional, predictable and driven by self-interest; Socrates is unswerving in his allegiance to principle, reason and truth.

Crito sees that he is making no headway and changes tack. Here is a paraphrase of what he says $(45 \mathrm{~b}-46 \mathrm{~b})$ :

Have no fear, Socrates, that we shall get into trouble by helping you to escape. Money is no object: we, your friends, have more than enough to pay the necessary bribes and all other expenses. You need not fear that you will feel

thought or the felicity of expression which is the mark of contemporary philosophy". Enough said! Recent perspectives on the Crito include Soper 1996, Weinrib 1982, Woozley 1979, Barker 1977, D'Amato 1976 and Congleton 1974. In this article, I follow Jowett's translation of the dialogue (Jowett 1937:427-438). I offer no excuse for doing so: according to Encyclopaedia Britannica, Jowett's translations of Plato remain the best available.

3 These events are memorably recorded in Plato's Apology.

4 See further $47 \mathrm{~d}$ where Socrates reiterates the point. Socrates displays here an anti-democratic attitude. But contra Martha Nussbaum (1997:25-28) who argues without citation of textual authority, that while Socrates is sympathetic to democracy, Plato is not. This view is untenable on two grounds: First, there is no textual basis for distinguishing the views of Socrates and Plato in this way. Secondly, Socrates, like Plato, displays a consistent aversion to democracy throughout the dialogues: see, for example, his ranking of the five forms of government in Books 8 and 9 of the Republic. (None of this in any way detracts from the validity of Nussbaum's thesis, with which 1 am entirely in agreement, that the method of Socratic inquiry could and ought to be employed by modern university students in addressing important contemporary issues.)

The subject of Plato's politics has sharply divided modern writers. His best known and most virulent critic is, no doubt, Karl Popper. For a conspectus of contemporary views including Popper's on Plato's ideal state, see Thorson (1963). 
estranged and alone in exile, away from Athens. Friends of mine in Thessaly will look after you. By staying here and forfeiting your life, you play into the hands of your enemies. Instead of bringing up and educating your children, you are content to die and so abandon them to their fate. This is unmanly dereliction of duty, the more so in one who professes virtue in all his actions. What will people think of us, your friends, who will be accused of negligence and cowardice for our failure to save you? There is no time to lose: decide now to escape.

These are all conventional arguments based on expediency or emotional manipulation. Indeed, Socrates' indifference to death and his willingness to let events take their course ("II]f such is the will of God, I am willing", 43e) stand in sharp contrast to Crito's anxious scheming and his desire to manipulate the outcome. Socrates is immune to manipulation. He listens carefully to Crito and announces that he will examine these arguments in the light of reason: "I am and always have been one of those natures who must be guided by reason" (46b). Reason is the very sap of the Platonic dialogues: it is the element which ensures their enduring freshness and vitality.

Socrates reaffirms (46c) his allegiance to the principles which he has always honoured and revered. ${ }^{5}$ These he will shortly turn to consider and apply. He scornfully declares that he is not to be swayed by the power of the multitude to inflict such "hobgoblin terrors" (46d) as imprisonment, confiscation of property, or death. ${ }^{6}$

Socrates proceeds $(46 \mathrm{~d}-48 \mathrm{c})$ to establish two premisses for the reasoning which will follow. He asks (47d):

In questions of just and unjust, fair and foul, good and evil...ought we to follow the opinion of the many and to fear them; or the opinion of the one man who has understanding? ...[W]ill life be worth having, if that higher part of man be destroyed, which is improved by justice and depraved by injustice?

Here are his answers $(48 \mathrm{a})$ :

We must not regard what the many say of us: but what he, the one man who has understanding of just and unjust, will say, and what the truth will say.

This then, is Socrates' first premiss: it raises questions. Who is the wise person that we ought to turn to for guidance? What if there is no such person to be found? How do we establish the dictates of truth in a given situation? This is not the place to explore such questions in depth. Suffice it to say that the answer to the last question has to be sought within ourselves, in the still depths of our being, by listening to the voice of conscience.

5 It was, I think, one of the Marx brothers who, somewhat unsocratically, said "These are my principles and, if you don't like them, I have others!"

6 The fearlessness displayed here by Socrates is recognized in Bhagavad Gita 16.1 as the first mark of the spiritual man.

7 Martin Prozesky (1999:16) errs in opposing this principle, although his call for a national ethics initiative in South Africa deserves to be widely supported. 
The contrast drawn here between the opinion of the many and that of the man of understanding is a theme which runs like a thread through the dialogue. This comparison, invariably favourable to the latter, is certainly controversial for our age, in which democracy is the unofficial state religion in many countries. Where does the truth lie? Is Socrates right, or are we? If Socrates is right, are we willing to act accordingly? ${ }^{8}$ These questions are surely inescapable for us.

Socrates turns to articulate his second premiss (48b): What is chiefly to be valued is not life itself, but a good life, that is, a just and honourable life.

From these two premisses, says Socrates, he will argue the question whether he would do rightly to escape in defiance of the Athenians. The considerations mentioned earlier by Crito, namely money, loss of reputation, and duty to educate children are, according to Socrates, merely the doctrines of the multitude, and so cannot be allowed to enter into the calculation (48b-d).

Socrates proceeds to formulate two principles which will form the basis of his decision. First, he says, the injuring of another can never be right. As he puts it, we ought not "...when injured, injure in return, as the many imagine; for we must injure no one at all...we ought not to retaliate or render evil for evil to any one, whatever evil we may have suffered from him...neither injury nor retaliation nor warding off evil by evil is ever right" (49b-d).

This principle is universal: it occurs, for example, in the Christian teaching, elsewhere in the Platonic dialogues,${ }^{10}$ in Justinian's codification of Roman law, ${ }^{11}$ and in Blackstone's (1765:40) Commentaries on the Laws of England. ${ }^{12}$ It is a precept which, as we shall see later, sets a demanding standard - too demanding, some would argue. Yet this precept alone could, if it were widely heeded, effect a fundamental shift in the present direction of human society.

Socrates' second principle, which Crito readily accepts, is that one ought always to do what one acknowledges to be right (49e). This principle emphasises that it is not enough to know what is right: one must also act in accordance with that knowledge. There must in other words, be congruence between knowledge and action. Failure so to act, all too common in practice, is well described by Socrates as betrayal of truth.

This brings us to the centrepiece of the dialogue, the imaginary conversation between the laws of Athens and Socrates. In one of the most graphic and powerful scenes in literature, Socrates imagines that, just as he is about to escape from the prison, the laws and government of Athens arrive to address and interrogate him. Even in the context of the Platonic dialogues, this interrogation is extraordinary for its richness of principle.

\footnotetext{
8 Are we willing, in other words, to follow the Socratic principle (49e) that one ought always to do what one acknowledges to be right?

$9 \quad$ Luke 6:29.

10 See, for example, Gorgias 475d-e; Republic 335; Domanski 1999:335-351 "The Quest for Justice in Plato's Republic".

11 Institutes 1.1.3.

12 Introduction 2.40.
} 
In addressing Socrates, the laws clearly, albeit implicitly, represent the voice of reason, the opinion of the one person, referred to earlier, who has understanding of justice and injustice. The laws begin by asking Socrates: "Do you imagine that a state can subsist and not be overthrown, in which the decisions of law have no power, but are set aside and trampled upon by individuals?" (55a-b).

This rhetorical question plainly implies that unlawful conduct by individuals, whether it take the form of murder, robbery, tax evasion, fraud, reckless driving, littering, or any other offence, major or minor, erodes the fabric of the state. For so long as respect for law is lacking in the individual citizen, this process of erosion is bound to accelerate. In political terms, the end result would, according to Plato, be a tyranny. ${ }^{13}$

Socrates considers whether he may argue, in reply to the question posed by the laws, that the unjust sentence imposed on him by the Athenian assembly justifies him in escaping from prison. ${ }^{14}$ To this, however, the rejoinder of the laws would surely be that his obligation to abide by the sentence is unconditional: it does not depend upon whether the sentence is just or unjust ${ }^{15}$. Moreover, to escape on this ground would be to return injury for injury, and thus violate a principle acknowledged by Socrates himself. ${ }^{16}$

The laws of Athens point out to Socrates that the individual is not on equal terms with the state." The rationale is that "since you were brought into the world and

13 Republic 562c-564a: here tyranny is stated to be the form of government which supersedes democracy when certain conditions are met.

14 This argument seeks to justify escape, not on the basis of any alleged injustice of the Athenian legal system itself - an allegation which Socrates nowhere makes, not even hypothetically-but on the alleged injustice of the sentence imposed by the assembly in a single instance. The question then arises: Would escape be justified in a state in which the legal system itself were widely held to be unjust and even illegitimate? The example leaps to mind of Nelson Mandela and others imprisoned on Robben Island under laws enacted by the apartheid regime in South Africa. Would they have been justified in escaping, given the opportunity? Is there not, in other words, a great difference between a single instance of unjust sentencing and a generally unjust legal system? Would an exception to the Socratic principle that it is never right to return injury for injury be justified in the example posited? Plato himself eventually arrived at the view that only when the state embodies the idea of the good can the individual properly be sacrificed to the state: see note 32 below.

15 On the competence of the Athenian assembly to try Socrates, and the legitimacy of the sentence imposed on him, see Taylor 1926:167-173.

$1649 \mathrm{a}-\mathrm{d}$. As the laws put it to Socrates (51a): "And because we think it right to destroy you, do you think that you have any right to destroy us in return, and your country as far as in you lies?" In his introduction to the Crito, Jowett (1900, vol.3:139) says: "Whether anyone who has been subjected by the laws of his country to an unjust judgment is right in attempting to escape is a thesis about which casuists may disagree... [T] here would be no difficulty in arguing that Socrates should have lived and preferred to a glorious death the good which he might still be able to perform...It may be remarked, however, that Plato never intended to answer the question of casuistry, but only to exhibit the ideal of patient virtue which refused to do the least evil in order to avoid the greatest, and to show Socrates, his master, maintaining in death the opinions which he had professed in his life."

$1750 \mathrm{e}$. There is no departure from this principle in the equality clause in the South African Bill of Rights: Section 9 of the Republic of South Africa Constitution Act 108 of 1996 (the Constitution) 
nurtured and educated by us, can you deny in the first place that you are our child..., as your fathers were before you?" (50d-e). It would follow that every individual is indebted to the country in which he was born, raised and educated. The laws go further: "[O]ur country is more to be valued and higher and holier far than mother or father or any ancestor, and more to be regarded in the eyes of the gods and of men of understanding" (51a). ${ }^{18}$

The notions that the individual owes duties to his country and family, and that country comes before family, have largely fallen into neglect today ${ }^{19}$ : our lop-sided concern understandably, given the legacy of apartheid, is the claiming, protection and enforcement of the rights of the individual. A reminder of the notions of duty and indebtedness, which serve to provide an important counterweight to this emphasis on rights, is therefore timely. It is hardly surprising that these notions, as well as the unarticulated underlying idea that the state is an organic living whole, of which the individual citizen is but a cell, have fallen upon evil times. Such notions have been adopted by totalitarian and repressive regimes, and that is enough to render them suspect in the eyes of many. ${ }^{20}$ More is the pity, for by such usurpation, values of universal validity have been turned to sordid political ends and so corrupted. This process, however, is surely not irreversible.

The duties of obedience and service specified in the Crito are owed only by those individuals who enjoy the full benefits of citizenship. ${ }^{21}$ This reciprocity between individual and state is plainly implicit in the tenor of the dialogue.

The allegiance and obedience owed by the citizen to his city and country are not unqualified. The laws of Athens tell Socrates that the citizen's fundamental duty, whether in battle, in court or elsewhere, is to do what his country requires of him. ${ }^{22}$

places all individuals on an equal basis and proscribes discrimination by the state against individuals. This provision does not, however, go so far as to place the individual on an equal footing with the state.

18 This is how Marsilio Ficino, leader of the Platonic Academy in Florence during the last Renaissance, describes the duty of the citizen (Ficino 1975 [1474]:124): "It is the duty of a citizen to consider the state as a single being formed of its citizens who are the parts; and that the parts should serve the whole, not the whole the parts. For when the profit of the part alone is sought, there is no profit at all for either part or whole. When, however, the good of the whole is sought the good of both is assured. Therefore, because of this connection, the citizen ought to remember that nothing good or bad can touch one limb of the state, without affecting the others and indeed the state as whole. And again, nothing can happen to the whole body of the state without soon affecting each limb."

19 There is, however, at least one provision in the Constitution which recognizes the importance of duties: see s3(2)(b).

20 See Stein \& Shand 1974:46.

21 Thus they would, in principle at least, bind citizens in post-apartheid South Africa. It would, of course, have been entirely unreasonable to impose these duties on all those South Africans who were denied basic freedoms and the benefits of citizenship under apartheid. From the tenor of the Crito, it is clear that neither Socrates nor Plato had in mind a state as deviant as South Africa under apartheid.

$2251 \mathrm{~b}$. The interesting question arises, however, whether the extent of the citizen's duty to obey the law ought not to depend on her ability to obey the law. For a brief discussion of this question, see Honoré 1995:101-102. 
Moreover, punishment imposed by one's country is to be "endured in silence" (51b). But in both cases it is open to a citizen to try to persuade her country or city to change their view of what is just $(51 \mathrm{~b})$. It follows that the citizen's voice must at least be heard in any matter in which she has an interest, although the state is under no obligation to follow the course of action which she proposes. Socrates himself, of course, was afforded a substantially fair trial by the Athenian assembly. If there was any injustice, it was in the contrived charges brought against him, not in the proceedings before the assembly. At his trial, Socrates was given the opportunity to put his case openly and fully.

The latitude afforded to the citizen by the Athenian state goes even further than this: the citizen is not required to abide by the laws of the country by reason only of the fact that he was born, nurtured and educated in that country. Once he comes of age, he may decide that he does not like his country, his city or their laws. In that event, he is free not only to emigrate, but also to take with him all his property. ${ }^{23}$ But the citizen who, having experienced the manner of government and the administration of justice in his country, chooses to stay is thereby and thenceforth bound by an implied contract to obey the laws. In the words of the laws of Athens: "[H]e who has experience of the manner in which we order justice and administer the state and still remains, has entered into an implied contract ${ }^{24}$ that he will do as we command him.",25

Even after the citizen has bound himself by this contract, however, it remains open to him at any time to try to persuade the state that the commands of its laws are unjust (52a). A view recently expressed by the Chief Justice (1998:21) is consonant with this principle: "Every citizen must have an unfettered right to make an informed input into the evolution of any common conviction on justice and moral values."

The balance thus struck, is in my view entirely reasonable and just. The citizen who, having elected to remain in the country, disobeys the laws, is: "....as we maintain, thrice wrong; first, because in disobeying us he is disobeying his parents; secondly, because we are the authors of his education; thirdly, because he has made an agreement with us that he will duly obey our commands" (51d-e).

I shall now focus on the third of these grounds. The thrust of it is that by disobeying the laws, the citizen in question commits an actionable breach of contract. It is worth noting that while this ground holds appeal for the lawyer, it is not essential or necessary as a legal basis for compelling obedience to law. After all, the state may

$2351 \mathrm{lc}-\mathrm{d}$. This goes much further than current South African law, which places limits on the amount of money that emigrants may take with them.

24 An implied contract, in the sense of a tacit obligation, arises by operation of law, in a manner analogous to contract; as where a person by some act binds himself to another just as if he had contracted with such other (Milne et al. 1951:801).

25 51d. Other translations of this key passage are as follows: "[I]f any one of you stands his ground when he can see how we administer justice and the rest of our public organization, we hold that by so doing he has in fact undertaken to do anything that we tell him..." (Tredennick 1954:92). "[I]f any one of you remains, when he sees in what manner we decide lawsuits and manage other public business, we say that he has now agreed in fact to do whatever we command..." (Rouse 1956:526-527). "[W]hoever of you remains, when he sees how we conduct our trials and manage the city in other ways, has in fact come to an agreement with us to obey our instructions" (Grube 1997:45). 
if it so wishes, dispense with this contractual ground and rest its case, in principle at least, on one or both of the first two grounds enumerated by the laws in this passage.

Lloyd (1964:55) plays down the importance of the contractual ground for a more fundamental reason, namely the recognition in the Crito that obedience to the law of the state is itself a principle of the highest morality. Watson (1977:127-128) echoes this view.

The implied contract comes into force only at the time when the citizen expressly or tacitly elects to remain in her country. Prior to that, it would follow, she is under no legal obligation towards the country that has given her birth, education and nurture. ${ }^{26}$ In so far as it is based on contract, the relationship between the individual and the state is plainly consensual in nature. In no sense can it be said that the citizen is coerced into entering the agreement. Thus, to the key question "Why ought I to obey the law?", Plato's simple yet startling answer is: "Because, whether you realize it or not, you have by your conduct agreed to do so." It is not possible here to explore the many implications of this principle. Consider but one obvious possibility: where a citizen commits a criminal offence, the state may, instead of prosecuting him, elect to sue him in civil law for breach of contract and seek an appropriate remedy, such as damages.

Is the implied contract between citizen and state, as envisaged in the Crito, not subject to a resolutive condition? The citizen's tacit undertaking to obey the laws would at first glance appear to be unconditional. But is it not necessary to read into the contract a term to the effect that the citizen remains bound to obey the laws only for so long as the fundamental character of the state "the very basis upon which he elected to remain in the country in the first place" does not change substantially for the worse? While this question is not explored in the Crito, it should in my view be answered in the affirmative, for to hold otherwise would surely be both unreasonable and unjust. In the words of Stein \& Shand (1974:47) ${ }^{27}$ :

There is an important assumption underlying Socrates' argument. The citizen's implied promise to obey the laws is not without qualification. It presumes that the laws are, at least as a whole, directed towards the good of the community, and are not, as a whole, unjust in the sense of distributing benefits and burdens unfairly. For this assumption to be justified, those who make the laws must be authorised by the general body of citizens, so that what they decide may approximate to the general will. In such a case it can be accepted that there is a prima facie case for regarding whatever is decided in detail as binding on the individual.

This qualification falls short of endorsing Dworkin's idea that whenever a law wrongfully invades the individual's rights against the state, he has the right to disobey it (Stein \& Shand 1974:47).

Plato, the father of Western philosophy, and his teacher, Socrates, were profoundly original thinkers: here in the Crito, for the first time in Western literature,

26 See Taylor 1926:168-169.

27 See further note 32 below. 
we find the relationship between the individual and the state expressed in contractual terms. There were, of course, many later writers of "footnotes to Plato" ${ }^{28}$ on this subject: Hobbes, Rousseau, Locke and Jefferson are probably the best known. Modern jurisprudence has generally tended to treat this principle as a product of recent centuries, ${ }^{29}$ thus overlooking Socrates and Plato, its ancient progenitors! It is most important that the record be set straight.

The reciprocal side of the contractual relationship between individual and state, namely the state's duty to "nurture and educate" (50d-e) the citizen, is hardly explored in the Crito. In particular, how far does this duty extend? Is it sufficient for the state merely to make available, free of charge, schooling up to secondary level, as is the case in many countries today? Or does Plato, by virtue of the term "nurture", require the state to go further, by ensuring that formal training is directed as strongly to the development of character as to the teaching of vocational skills? And if so, does the state's duty to "nurture and educate" come to an end once such formal training has been completed? The reader who wishes to pursue these questions is referred to Plato's extensive treatment of education elsewhere in the dialogues. ${ }^{30}$

The laws of Athens, turning now from the general to the particular, proceed to remind Socrates that he above all others has, by his conduct, acknowledged the implied contract and is therefore bound to honour it (52a). Only once during his long life did Socrates set foot outside Athens: unlike others, he had no interest in travel or in learning about other countries; he has had seventy years in which to reflect on the covenants he made at his leisure with the city and its laws; during that time, he could, had he so chosen, have emigrated; it was in Athens that he begot his children; he could, in the course of his trial, have fixed the penalty at exile rather than death, had he so chosen: but having decided before the assembly that he preferred death to exile, he would not be acting consistently if he were now to escape into exile (52a-e).

If Socrates were to choose to escape, what consequences would follow? To destroy the laws by running away and forsaking his agreements, freely entered into, would be the conduct of a "miserable slave" (52c-53a); patriotic citizens would regard him as a subverter of the laws; those who condemned him in his trial would now feel vindicated; his frequent utterances about the importance of virtue, justice and law would henceforth be dismissed as mere lip-service; while he might perhaps find refuge in some other state, an undignified life in exile would hardly be worth living; by taking his children into exile with him, he would deprive them of the benefits of Athenian citizenship, whereas, if he dies, his friends here in Athens would surely take care of them $(53 b-54 b)$.

28 In the famous and entirely apt words of Whitehead (1978:63): "The safest general characterisation of the European philosophical tradition is that it consists of a series of footnotes to Plato."

29 See, for example Harris 1980:212.

30 Notably in the Republic and the Laws. 
The laws, in conclusion, urge Socrates to put justice before life and children (54b) ${ }^{31}$ Socrates, if he submits to the sentence, will "depart in innocence, a sufferer and not a doer of evil; a victim, not of the laws, but of men" (54c) ${ }^{32}$ To escape, on the other hand, would be, first, to return evil for evil and injury for injury, and thus to violate the first principle established earlier by Socrates himself $(49 \mathrm{~b}-\mathrm{d}) .{ }^{33}$ Secondly, such conduct would, as we have seen, constitute a breach of contract.

Is there a valid distinction between the citizen's duty to abide by a sentence imposed on her by a competent court, and the duty to obey the law of the state generally? ${ }^{34}$ I would argue that there is not, although there appears to be force in Watson's view $(1977: 128)^{35}$ :

[I] $\mathrm{t}$ may be asked whether the question of duty in obeying the law might not be put more sharply in the form. Is there a duty to obey a decision in the legal process? It is a characteristic of law that it is not always strictly enforced. In the situation now under discussion, the officers of the state have decided to take action. Someone who refuses to obey the court decision is thus setting himself in opposition to the state in a particularly strong way. The authority of the state is being strongly and directly challenged not necessarily the case where one disobeys the law and the effect on order is likely to be marked. Moreover, the disobedience of a court decision will be public in a way that is not usually true of disobedience of legal rule.

Socrates surrenders to the voice of reason; his decision is made. In a moving finale, he declares his allegiance to that voice (54d): "This, dear Crito, is the voice which I seem to hear murmuring in my ears like the sounds of the flute in the ears of

31 Justice is an essential element of the relationship between the citizen and the state; it is a constant refrain in the Crito, as it is in other Platonic dialogues, for example, the Republic, Protagoras, Gorgias and Laws.

32 According to Lloyd (1964:55): "[T]he idea that to live according to the laws was the highest unwritten law...might, as...in the case of Socrates, result in those laws requiring the justest man to die. To this dilemma Plato himself later propounded his own solution, that only when the state itself embodied the idea of the good could the individual properly be sacrificed to the state." This last point was echoed by the Chief Justice in his tribute to Bram Fischer (1998:21). Fischer's credo amounted to this: "There must be a rational and purposive relationship between law and morality, and particularly between law and justice. The law must have a morally defensible content. It is that which compels my fidelity to it. Your laws do not have that content. They are immoral. I am therefore not obliged to obey them. Indeed I am entitled to defy them with the object of causing other laws to be enacted which can properly compel my fidelity."

See further note 14 and text to note 27 above.

33 See note 16 and text thereto.

34 A lawyer may be tempted to argue that the "judgment" of the laws of Athens must be restricted to the facts of Socrates' case. On this technical view, the case is authority only for the proposition that the citizen has a duty to abide by the sentence imposed on her by a competent court, but no duty to obey the law generally. It would then follow that much of what the laws say is "obiter"! Appealing though such a narrow interpretation of the Crito may be to modern positivist thinking, Socrates and Plato (though perhaps not Aristotle) would surely reject it out of hand.

35 See further Daube 1972:77. 
the mystic; that voice, I say, is humming in my ears and prevents me from hearing any other. And I know that anything more which you may say will be in vain. ${ }^{36}$ Crito bows to the inevitable.

Socrates, in asking Crito to leave him to fulfil the will of God, ${ }^{37}$ prepares to put into practice the second principle which he established earlier (49e) ${ }^{38}$ : having decided what is right, he acts accordingly. Socrates' act of submission represents the final harmonization of the positive law of Athens with the higher law..$^{39}$

The hallmarks of the relationship between the citizen and the ideal state, as portrayed in the Crito, are justice, duty and trust. With the state cast in the role of parent, educator and nourisher of the citizen, it is trust, above all, which emerges as the key element in the relationship. Only if the state, as the more powerful party to the relationship, fulfils these functions properly will a climate of trust be created in which the citizen feels bound to obey the laws of the state. In the absence of trust, the relationship cannot work, and lawlessness must then prevail.

Trust is a value which we generally prefer to confine to the private realm of interpersonal relationships. To enthrone it as the key element in the relationship between state and citizen would strike many as bizarre. Yet this is precisely what is called for by the Socratic-Platonic model presented in the Crito: it is trust that has to be brought into our public life. Once that is done, the fulfilment of the reciprocal obligations tied up in the implied contract between state and citizen ought to follow as a matter of course. Many will dismiss this statement as glib, and the Socratic-Platonic model as utopian. And indeed, the establishment of the necessary trust would be no easy task. Yet this model sets the standard to aim at: we ought not to lower our sights and settle for less.

It is hardly surprising that this model of the relationship between citizen and state is nowhere in evidence today: in many modern countries the state is understandably viewed as a powerful manipulative force, cynical, self-seeking, indifferent to the real welfare of its citizens and generally not to be trusted. ${ }^{40}$ Armslength dealing is usually the hallmark of the relationship. The reciprocal duties of the parties - "the state's duty to educate and nourish the citizen, and the citizen's duty to obey the law"-are largely neglected on both sides. In the prevailing climate of mistrust between citizen and state, it is small wonder that individuals feel the need to

36 In this passage, Plato employs the second of the metaphors that give the Crito its dramatic force: the first is the personification of the laws and the state; the second, used to explain why Socrates feels compelled to act in accordance with reason, is the metaphor of possession by the gods.

37 So much for the labelling of Socrates as a "pagan philosopher" by the Christian church. (Christ himself, of course, would never have applied such a label to him.) Where does true spirituality lie: in nobility of conduct or in the formal dogma of institutional religion?

38 The principle, we will recall, is that one ought always to do what one accepts to be right.

39 Lloyd (1964:55) points out the difference between ancient Greek and Hebraic law: "The Hebrew view...insists that human law is to be obeyed only when it corresponds with divine law; the Greek view, on the other hand, is that human law may conflict with moral law, but the citizen must still obey the law of his state, though he may and indeed should labour to persuade the state to change its law to conform with morality."

40 I speak here of Western democracies in which a normal political process operates; a fortiori in South Africa as it was under apartheid, or in most countries of the third world. 
have fundamental human rights constitutionally protected against the power of government.

The Socratic-Platonic model of the relationship between state and citizen is founded on absolute, unchanging values of reason, justice and truth. This model, therefore, provides a standard of universal validity: it is applicable everywhere and at all times, although its application will, of course, need to be modified to meet the particular needs of time and place.

Examples of obedience to law, historical and contemporary, dramatic and mundane, domestic and foreign, are not far to seek. Here are two. The first is a most instructive episode from the life of Henry the Fifth (Tumim 1985:9-10):

The most renowned prince, King Henry the Fifth, late King of England, during the life of his father was noted to be fierce and of wanton courage. It happened that one of his servants, whom he well favoured, for felony by him committed, was arraigned at the King's Bench; whereof the Prince being advertised, and incensed by light persons about him, in furious rage came hastily to the Bar, where his servant stood as a prisoner, and commanded him to be ungyved and set at liberty whereat all men were abashed, observed the Chief Justice, who humbly exhorted the Prince to be contented that his servant might be ordered according to the ancient laws of this realm, or if he would have him saved from the rigour of the laws, that he should obtain, if he might, of the King his father, his gracious pardon; whereby no law or justice should be derogate. With which answer the Prince nothing appeased, but rather more inflamed, endeavoured himself to take away his servant. The judge considering the perilous example and inconvenience that might thereby ensue, with a valiant spirit and courage commanded the Prince upon his allegiance to leave the prisoner and depart his way. With which commandment the Prince, being set all in a fury, all chafed, and in a terrible manner, came up to the place of judgment men thinking that he would have slain the judge, or have done to him some damage; but the judge sitting still, without moving, declaring the majesty of the king's place of judgment, and with an assured and bold countenance, had to the Prince these words following: "Sir, remember yourself; I keep here the place of the king, your sovereign lord and father, to whom you owe double obedience; wherefore eftsones in his name I charge you to desist of your wilfulness and unlawful enterprise, and from henceforth give good example to those which hereafter shall be your proper subjects. And now for your contempt and disobedience, go you to the prison of the King's Bench, whereunto I commit you; and remain you there prisoner until the pleasure of the King your father be further known."

With which words being abashed, and also wondering at the marvellous gravity of that worshipful justice, the noble Prince, laying his weapon apart, doing reverence, departed, and went to the Prison as he was commanded. Whereat his servants disdaining came and showed to the King all the whole affair. Whereat the King a while studying, after as a man all ravished with gladness, holding his eyes and hands up towards heaven, 
abraided, saying with a loud voice, "O merciful God, how much am I, above all other men, bound to your infinite goodness; especially for that you have given me a judge, who feareth not to minister justice, and also a son who can suffer and obey justice".

An equally inspiring example from more recent times is ex-President Mandela's obedience to an order to appear to give evidence in court in the SARFU case. ${ }^{41}$

Before the Socratic-Platonic model can assume its rightful place in political practice, trust between citizen and state must be created on a widespread and ongoing basis. Only then will the contemporary clamour for rights give way to a willingness to carry out the duties called for by that model; only then will we be able to say with Justinian $^{42}$ : "[T] authority of enacted law, which disposes well things both divine and human, and expels all iniquity." 43

It goes without saying that for as long as corruption, crime and nepotism are rife within government, the trust necessary to found a culture of obedience to law cannot be formed. The advent of a new millennium should be seen as an opportunity to wipe the slate clean and to begin afresh along Socratic lines. Such a radical change of direction in the polity of a country would obviously require an abundance of goodwill on all sides. In the midst of the problems that beset us in South Africa today, goodwill is surely one commodity that is not lacking.

\section{BIBLIOGRAPHY}

Barker, A 1977. Why did Socrates refuse to escape? Phronesis 22:13-28.

Blackstone, W 1983 [1765]. Commentaries on the Laws of England. Vol.1, Reprint. New York: The Legal Classics Library Division of Gryphon Editions.

Congleton, A 1974. Two kinds of lawlessness: Plato's Crito. Political Theory 2.4:432-446.

D'Amato, A 1976. Obligation to obey the law: A study of the death of Socrates. Southern California Law Review 49.5:1079-1108.

Daube, D 1972. Civil disobedience in antiquity. Edinburgh: Edinburgh University Press.

Domanski, A 1999. The quest for justice in Plato's Republic. Tydskrif vir hedendaagse Romeins-Hollandse reg 62:335-351.

Ficino, M 1975 [1474]. The letters of Marsilio Ficino. Translated from the Latin by members of the Language Department of the School of Economic Science. London: Shepheard-Walwyn.

Grube, G M A (trans.) 1977. In Cooper, J M (ed) Plato: Complete works. Indianapolis: Hackett Publishing Company.

41 President of the RSA v South African Rugby Football Union 1999 (2) SA 14 (CC) at 17A-B.

42 Constitutio Deo Auctore, quoted in Watson 1977:119.

43 According to Watson (1977:120), a sense of the supreme importance of law for the well-being of the state has been the mark of such great legislators as Justinian and Napoleon. 
Harris, J W 1980. Legal philosophies. London: Butterworths.

Honoré, T 1995. About law: An introduction. Oxford: Clarendon Press/Oxford University Press.

Jowett, B (trans.) 1937 [1892]. The dialogues of Plato. Vol.1. $3^{\text {rd }}$ ed. Reprint. New York: Random House.

Jowett, B 1900. Works of Plato. New York: Tudor.

Lloyd, D 1964. The idea of law. Harmondsworth: Penguin.

Mahomed, I 1998. Laws must be built on justice-or be disobeyed. The Sunday Times: Sunday Analysis. 8 February 1998:21.

Milne, A A, Cooper, C \& Burne, B D 1951 Bell's South African legal dictionary. $3^{\text {rd }}$ ed. Durban: Butterworths.

Nussbaum, M 1997. Cultivating humanity: A classical defence of reform in liberal education. Cambridge: Harvard University Press.

Prozesky, M 1999. Morality of the people, by the people and for the people. The Sunday Times: Sunday Analysis. 11 July 1999:16.

Rouse W H D (trans.), Warmington, E H \& Rouse, P G (eds) 1956. Great dialogues of Plato. New York: New American Library.

Soper, P 1996. Another look at the Crito. American Journal of Jurisprudence 41:103132.

Stein, P \& Shand, J 1974. Legal values in Western society. Edinburgh: Edinburgh University Press.

Taylor, A E 1926. Plato: The man and his work. London: Methuen.

Thorson, T L (ed.) 1963. Plato, totalitarian or democrat. Englewood Cliffs: Prentice Hall.

Tredennick, H (trans.) 1954. The last days of Socrates. Harmondsworth: Penguin.

Tumim, S 1985. Great legal fiascos. London: Arthur Baker.

Vlastos, G L 1974. Socrates on political obedience and disobedience. Yale Review 63.4:517-534.

Watson, A 1977. The nature of law. Edinburgh: Edinburgh University Press.

Weinrib, E J 1982. Obedience to the law in Plato's Crito. American Journal of Jurisprudence 27:85-108.

Whitehead, A N 1978 [1929]. Process and reality: an essay in cosmology. Gifford Lectures delivered in the University of Edinburgh during the session 19271928. Griffin, D R \& Sherburne D W (correctors). New York: Free Press.

Woozley, A D 1979. Law and obedience: The argument of Plato's Crito. London: Duckworth. 